\title{
Effective supervision of inland capture fisheries of Bangladesh and its hurdles in managing the resources
}

\author{
A. K. M. Firoz Khan ${ }^{*}$, M. G. Mustafa ${ }^{1}$ and M. Niamul Naser $^{2}$
}

*Correspondence:
F.Khan@cgiar.org
1The WorldFish Center,
Bangladesh and South Asia
office, House 22B, Road 7,
Block F Banani, Dhaka 1213,
Bangladesh
Full list of author information
is available at the end of the
article

*Correspondence:

F.Khan@cgiar.org

The WorldFish Center, office, House 22B, Road 7, Block F Banani, Dhaka 1213, Bangladesh article

\begin{abstract}
Community-based approaches have gained significant attention in inland open water fisheries management in Bangladesh. This article focuses on the challenges and opportunities of the inland open water fishery resources under community-based management approaches. The present study employed management information of waterbodies between 1991 and 2014 across a range of geographical locations and habitats. The study reveals that coordinated management of water bodies is essential given common management issues of waterbodies. Present study also reveals that complexity of different property rights and the diversity of users within individual clusters have had cumulatively adverse effects on fisheries. The study shows that different fisheries management policies promoted by the government of Bangladesh over time to have varied in strength and appropriateness. This study concludes that open water fisheries management through fishers' community involvement is promising approach in Bangladesh but a variety of socio-economic factors that affect the governance in its implementation.
\end{abstract}

Keywords: Open water fisheries, Challenges, Community involvement, Bangladesh

\section{Background}

Bangladesh is basically a low lying flat land country, is endowed with enormous inland fishery resources which contribute a significant part of freshwater fish production. Inland fisheries in Bangladesh contain different types of water bodies' character e.g. flowing rivers, beel-usually deeper depression in the floodplain, haor-extensive low lying areas comprising several perennial beels and baor or oxbow lakes or dead rivers that have lost their connectivity with the main stream. To assess the status of fisheries resources and current management practices and to test and access alternative local fishery management arrangement that might achieve greater efficiency, equity and sustainability a Community Based Fisheries Management (CBFM) was established in inland fisheries sector in Bangladesh (Sultana and Thompson, 2000).

Inland fisheries management is complex by its physical condition and variety of stakeholder's involvement in resource exploitation process. About four million hectare of open water in Bangladesh are the rivers, beels (permanent and seasonal lakes and wetlands), baors (oxbow lakes), haors (large deeply flooded depressions), and floodplains

(C) 2015 Firoz Khan et al.. This article is distributed under the terms of the Creative Commons Attribution 4.0 International License (http://creativecommons.org/licenses/by/4.0/), which permits unrestricted use, distribution, and reproduction in any medium, provided you give appropriate credit to the original author(s) and the source, provide a link to the Creative Commons license, and indicate if changes were made. 
provides more than 264 fish species (Rahman, 2005). Government of Bangladesh made waterbody management policy for conservation, increased production and bio diversity conservation of fisheries resources as well as leasing government waterbodies in favour of real fishers, and earn revenue. Present waterbody leasing policy does not provide secured access of the fisher communities and management. Policy allowing influential people to back different fisher groups to leased by bidding in a tender process but would limit opportunities to bestow political patronage.

Waterbody leasing policy had changed over time. In 1984 waterbodies ranging from 3-20 acres were under the jurisdiction of Upazila ${ }^{1}$ Nirbahi Officers (UNO), while waterbodies more than 20 acres were placed with Additional Deputy Commissioner (ADC) Revenue under jurisdiction of the Ministry of Land (MoL). The first move towards open water fisheries management started in 1985 through the introduction of New Fisheries Management Policy (NFMP) to secure better access right to the "genuine fisheries" by identifying real fishermen. In 1994 Government adopted a policy to transfer management of smaller waterbodies to the local Government bodies (Union Parishad, ${ }^{2}$ Municipalities and City corporations). In 1997 smaller waterbodies (up to 20 acres) were transferred to the Ministry of Youth and Sports (MoYS) to create income opportunities for youth societies, but this initiative was unable to achieve its target due to vested interested groups created fake youth societies to grab these resources (Huda 2003). The main fisheries policy changed in 1995 by declaring "free access to open waterbodies" in order to remove difficulties faced by fisher groups. However, this declaration made open water fisheries management more difficult, as local muscle men took advantage of the open access by excluding poor people from the resources thus, unlimited access for fishing was established. In Bangladesh fisheries users can be divided into three categories-fulltime professional fisher, part time seasonal fisher and subsistence fisher fish for consumption.

In most cases fisheries management initiatives not sustained due to improper identification of fisher categories. Most of the policy adopted by the government to administer fisheries resources properly, while, existing wide range of interest groups gain illegal benefits from these fisheries. However, various management approaches have been attempted to enhance fisheries returns.

The purpose of this paper is to provide background information on the fisheries of Bangladesh and to justify the implementation of community-based fisheries management (CBFM) as vital if sustainable solutions are to be found.

\section{Method}

The present paper assesses various community based projects and polices of the government of Bangladesh. The Improved Management of Open Water Fisheries project from 1991 to 1994 was first piloted in through the concept on community based management. The later CBFM Phase I and II, Community Based Fisheries Management in South and South East Asia (CBFM-SSEA), SCBRMP, Fourth Fisheries Project (FFP) and Management of Aquatic Ecosystems through Community Husbandry (MACH) projects were

\footnotetext{
${ }^{1}$ An Upazila is the sub-district level administrative unit.

${ }^{2}$ Union Parishad is the smallest administrative unit.
} 
subsequently developed (Thompson and Hossain 1998, Thompson et al. 1999, Thompson 2004, Thompson et al. 2004, Dickson and Usha 2006, Dickson 2006, Khan and Middendrop 2006, Kuperan et al. 2003, IFAD 2006, Mustafa et al. 2007). A list of assessed projects those has been completed between 1991 and 2014 is presented in Table 1.

Simultaneously the prospects and problems of open water fisheries management are identified from the publication, project reports, and gray literature as well as from the field. Possible guidelines for improved governess have been proposed in conclusion and recommendation.

\section{Review}

\section{Challenges of the community-based fisheries}

Projects finding reveals that inland capture fisheries resources are ensuring food, income, and employment of millions of poor people in the developing countries like Bangladesh. However, these vital resources are under high pressure, and over-exploitation and degradation of habitat, and often ignored the socio economic aspects fisheries. Hence, community-based management approach introduced to countries face major constraints in capacity and the ability to promote implementation of long-term sustainable policies.

Table 1 Projects involving communities and inland fisheries management of Bangladesh

\begin{tabular}{|c|c|c|c|}
\hline Project name & Donor & Executed organization & Duration \\
\hline $\begin{array}{l}\text { Improved management } \\
\text { of open water fisheries }\end{array}$ & Ford foundation & $\begin{array}{l}\text { DoF, WorldFish (previous } \\
\text { ICLARM), BRAC, Proshika and } \\
\text { friends in village development }\end{array}$ & 1991-1994 \\
\hline $\begin{array}{l}\text { Oxbow lakes small scale fisher- } \\
\text { men's project-phase II }\end{array}$ & IFAD and DANIDA & DoF and BRAC & 1991-1997 \\
\hline $\begin{array}{l}\text { Compartmentalization pilot } \\
\text { project (CPP) }\end{array}$ & GOB, FRG and the Dutch & $\begin{array}{l}\text { BWDB and a number of NGOs at } \\
\text { different times }\end{array}$ & $1991-2000$ \\
\hline $\begin{array}{l}\text { Community based fisheries devel- } \\
\text { opment and habitat restoration } \\
\text { project-phase I }\end{array}$ & -Ford foundation & CNRS and Proshika & 1994-1997 \\
\hline $\begin{array}{l}\text { Community based fisheries man- } \\
\text { agement (CBFM)-phase I }\end{array}$ & Ford foundation & \multicolumn{2}{|c|}{$\begin{array}{l}\text { DoF, worldfish (previous ICLARM), 1995-1999 } \\
\text { Caritas, Proshika, BRAC and } \\
\text { Banchte Shekha }\end{array}$} \\
\hline $\begin{array}{l}\text { Management of aquatic eco- } \\
\text { systems through community } \\
\text { husbandry project (MACH) }\end{array}$ & USAID & \multicolumn{2}{|c|}{$\begin{array}{l}\text { Winrock international, DoF, BCAS, 1998-2008 } \\
\text { CNRS and Caritas }\end{array}$} \\
\hline $\begin{array}{l}\text { Dampara water improvement } \\
\text { project }\end{array}$ & GOB and CIDA & BWDB, DoF, NACOM and Tara & 1998-2001 \\
\hline $\begin{array}{l}\text { Fourth fisheries project (inland } \\
\text { fisheries component) }\end{array}$ & $\begin{array}{l}\text { GOB, IDA, GEF, DFID } \\
\text { and beneficiaries }\end{array}$ & $\begin{array}{l}\text { DoF, BWDB, LGED, NGOs and } \\
\text { local fishing communities }\end{array}$ & 1999-2004 \\
\hline $\begin{array}{l}\text { Sustainable environment man- } \\
\text { agement program (fisheries } \\
\text { component) }\end{array}$ & UNDP & $\begin{array}{l}\text { DoF, IUCN, CNRS, NACOM and } \\
\text { BCAS }\end{array}$ & $2000-2003$ \\
\hline $\begin{array}{l}\text { Community based fisheries man- } \\
\text { agement in south and south } \\
\text { East Asia (CBFM-SSEA) }\end{array}$ & IFAD & $\begin{array}{l}\text { DoF, WorldFish (previous } \\
\text { ICLARM), ERA, SUJON }\end{array}$ & $2001-2007$ \\
\hline $\begin{array}{l}\text { Community based fisheries man- } \\
\text { agement (CBFM)-phase II }\end{array}$ & DFID & $\begin{array}{l}\text { WorldFish (previous ICLARM), } \\
\text { DoF, BELA, BRAC, CNRS, } \\
\text { Banchte Sheka, Caritas, Fem- } \\
\text { com and Proshika }\end{array}$ & 2001-2006 \\
\hline $\begin{array}{l}\text { Sunamganj community based } \\
\text { resource management project } \\
\text { (fisheries component) }\end{array}$ & GOB and IFAD & $\begin{array}{l}\text { LGED, MoL, DoF, DAE, DoL, BKB, } \\
\text { worldfish and local NGOs }\end{array}$ & \\
\hline
\end{tabular}


International concern about people and their resources has significantly impacted thinking about how fisheries should be managed and the need for greater responsibility by fishers and managers is becoming more frequently heard. This situation urgently requires effective management measures which can be best achieved by involving all user groups and the national fisheries agency, as the leader of the managers, for long term success oriented ultimately towards societal well-being, and based upon economic and resource sustainability. However, the involvement of fishers in management is in many cases limited to consultation on implementation issues, but may also involve the development of shared understandings and knowledge basis for management.

\section{Policy level}

Government policy always meant for common resources enhancement to eradicate poverty. Thus policy should hinder influential people to extract resources for their own interest, however, in reality present policy does not support poor people, musclemen are grabbing in association with politicians.

Waterbody leasing policy had been changed in different years and mostly starts from 1984 in Bangladesh. Waterbodies ranging from 3-20 acres were under the jurisdiction of Upazila (sub-district) Nirbahi (executive) Officer (UNO) while water bodies more than 20 acres had been placed with ADC Revenue at district level and directed by the MoL.

The first move towards inland open water fisheries management started in 1985 with the introduction of the NFMP. Under the new policy the lease money would be fixed at $10 \%$ above average revenue for the previous 3 years from the concerned waterbodies (Jalmahal). The Department of Fisheries was responsible for collecting lease money and ensuring conservation of fisheries resources. District level committees under the chairmanship of the Deputy Commissioner (DC) and a national level committee under the chairmanship of the Secretary, Ministry of Fisheries and Livestock (MOFL) were set up with detailed terms of reference for guidance, supervision and monitoring of the operation of the NFMP. This policy initially applied to a limited number of waterbodies on an experimental basis, but before the system could take root it was virtually abandoned by a government declaration in 1995 which granted open access to inland open waterbodies mostly flowing rivers. Subsequent analysis of the experiment has shown the potential of the NFMP in securing access to the majority of the fishers. The introduction of a licensing system for conferring fishing rights to genuine fishers provided a sound policy framework on the basis of which an access system could have been developed. The NFMP had the effect of drawing the attention of government officials to the potential to break the existing hierarchy at different levels of the government, but it is apparent that government officials are preferred to collect revenues from a handful of fisher leaders rather than helping poor fishers for the fisheries management in general.

Simultaneously Government had undertaken another policy for inland open water fisheries management in 1994, and decided to transfer smaller waterbodies (under 3 acres) to the Local Government bodies (Union Parishad, Municipalities and City Corporations). Another management decision undertaken by the Government in 1997 was to transfer smaller water bodies up to ( 20 acres) to the MoYS to create income opportunities for youth societies. However, this initiative was not properly implemented by the local 'youth societies' which were used as a front by influential groups who formed 
'youth societies' as a front for gaining control over all smaller water bodies, with the result that the goal of the policy was not achieved.

The policy shift in 1995 was the most controversial among all inland capture fisheries policies. The main motive of the declaration was to remove the difficulties faced by fisher groups. However, since 1995 the end to leasing and resultant free access in flowing rivers has encouraged overfishing and locally powerful people and fishers have been able to gain control over section of river and have invested more heavily in boats and destructive fishing gears such as fish aggregating devices (FADs), (Mustafa, 2009). This system made open water fisheries management more difficult, and encouraged the indiscriminate exploitation of open water fisheries resources. The policy created uneven competition between local muscle men and poor fishers, with the effect that musclemen were able to take advantage of open access, and poor fishers were adversely affected as they could not compete with against the more powerful class of people. The unlimited access for fishing fosters unlimited mismanagement.

The system of awarding leases with duration of 1-3 years to the highest bidder is essentially incompatible with conservation since it encourages maximum exploitation in the short term as there is no incentive to invest in conservation for the future (Huda, 2003). Besides, lack of awareness by the resource user, manpower by the law enforcing agencies, inter-organizational conflicts etc., are the major concern averting the law in enforce (Naser 2014).

\section{Waterbody leasing procedure}

Historically government has adopted a revenue-oriented leasing method for inland capture fisheries. Under the existing leasing system genuine fishermen are deprived of fishing rights as they are unable to compete against wealthy middlemen in the bidding processes. In order to secure fishing rights fishermen must pay money or a share of their catch to the lease holder. Due to the short term nature of the leasing systems, the lease holders do not derive any incentive to undertake conservation measures; rather they harvest as much fish as possible in order to obtain maximum benefit. Furthermore, the overall contribution of waterbodies to government revenue is nominal and in 2000 contributed only about $0.07 \%$ of total government revenue (BBS 2001). Table 2 shows that the revenue from waterbodies larger than 20 acres from 1997 to 2001 (Huda 2003). However, despite the limited importance of leases as a source of government revenue,

Table 2 Revenue earnings from Jalmahal above 20 Acres during Bengali year (B.S) of 1404-1408 B.S (Million Taka, I USD = 78 Taka) in Bangladesh

\begin{tabular}{lccccc}
\hline Name of the division & $\mathbf{1 4 0 4}$ B.S & 1405 B.S & 1406 B.S & 1407 B.S & $\mathbf{1 4 0 8}$ B.S \\
\hline Dhaka & 3.67 & 0.451 & 4.43 & 4.78 & 4.52 \\
Chittagong & 0.912 & 0.861 & 0.993 & 1.26 & 1.26 \\
Rajshahi & 0.972 & 1.092 & 1.30 & 1.41 & 1.54 \\
Khulna & 5.63 & 1.564 & 1.31 & 1.60 & 1.62 \\
Sylhet & 6.71 & 6.436 & 0.038 & 6.34 & 6.64 \\
Barisal & 0.038 & 0.038 & 15.78 & 15.44 & 0.065 \\
Total (taka) & 17.93 & 10.45 & & 15.68 \\
\hline
\end{tabular}

Source: ministry of land, government of Bangladesh

B.S. Bengali year 
the ability of elected officials to grant leases to favoured individuals or groups is important securing political backing at the local level, meaning that there is little incentive to adopt policies with better management outcomes.

\section{Inconsistency in fixation lease value}

The system for determining lease values has creates scope for misappropriation of resources by some vested interest groups in government and society at large. Table 3 and 4 provides an example of lease cost variability from two large community-based fisheries management projects. In the CBFM-2 project there is a big variation in revenue collection ranging from Taka 53-42,455/ha in 2002-2003.

Inconsistency of lease value setting is still persisting. The SCBRMP was the biggest fisheries management project in Bangladesh. Fixation of land revenue in the SCBRMP's waterbodies has not been made in a transparent manner; this procedure neither followed criteria based on bio-logical productivity nor waterbody area. This poverty alleviation project has had to pay the incremental lease value along with value added tax, thus Table 4 shows a wide variation of lease value among waterbodies, with the result that some lease values are very high while others are very low.

\section{Mechanisms in setting the value of leases}

The productivity of a waterbody varies greatly depending on geographical region, physical characteristics, fisheries biology, and the variable extent of water in any given year, while, the number of fishing households dependent these resources have no fixed

Table 3 Lease values of selected waterbodies under CBFM-2 project in Bangladesh

\begin{tabular}{|c|c|c|c|c|c|c|}
\hline $\begin{array}{l}\text { Name of the } \\
\text { Water body }\end{array}$ & $\begin{array}{l}\text { Waterbody } \\
\text { location } \\
\text { (Upazila } \\
\text { and District) }\end{array}$ & $\begin{array}{l}\text { Waterbody } \\
\text { area (ha) }\end{array}$ & $\begin{array}{l}\text { Lease value } \\
\text { (Tk.per ha) } \\
\text { in } 2000- \\
2001\end{array}$ & $\begin{array}{l}\text { Lease value } \\
\text { (Tk. per ha) } \\
\text { in } 2002- \\
2003\end{array}$ & $\begin{array}{l}\text { Lease value } \\
\text { increased (\%) }\end{array}$ & Comments \\
\hline $\begin{array}{l}\text { Betaldoba Sar- } \\
\text { bamongal }\end{array}$ & $\begin{array}{l}\text { Kotiadi, } \\
\text { kishoreganj }\end{array}$ & 20 & 28,781 & 42,455 & 48 & $\begin{array}{l}\text { Very high lease } \\
\text { value }\end{array}$ \\
\hline $\begin{array}{l}\text { Nalia Karma } \\
\text { Beel }\end{array}$ & $\begin{array}{l}\text { Karimganj, } \\
\text { kishoreganj }\end{array}$ & 36 & 6694 & 9874 & 49 & \\
\hline $\begin{array}{l}\text { Beel Hatina } \\
\text { Moral }\end{array}$ & $\begin{array}{l}\text { Akhaura, brah- } \\
\text { manbaria }\end{array}$ & 35 & 8857 & 9482 & 11 & \\
\hline Rajdhola Beel & $\begin{array}{l}\text { Purbadhala, } \\
\text { netrokona }\end{array}$ & 50 & 5000 & 8638 & 73 & \\
\hline $\begin{array}{c}\text { Beel Shakla } \\
\text { Jalmahal }\end{array}$ & $\begin{array}{l}\text { Sadar, brahman- } \\
\text { baria }\end{array}$ & 76 & 5513 & 6889 & 25 & \\
\hline $\begin{array}{l}\text { Beel Hurul } \\
\text { Fishery }\end{array}$ & $\begin{array}{l}\text { Nasirnagar, brah- } \\
\text { manbaria }\end{array}$ & -336 & 714 & 891 & 25 & $\begin{array}{l}\text { Low lease } \\
\text { value }\end{array}$ \\
\hline $\begin{array}{l}\text { Meda Beel Tunai } \\
\text { Bari Khal }\end{array}$ & $\begin{array}{l}\text { iKalmakanda, } \\
\text { netrokona }\end{array}$ & 18 & 556 & 819 & 47 & \\
\hline Atrai Beel & Pirganj, rangpur & 19 & 263 & 378 & 44 & \\
\hline Ashurar Beel & $\begin{array}{l}\text { Nawabganj, } \\
\text { dinajpur }\end{array}$ & 350 & 121 & 121 & 0 & \\
\hline Haily Beel & $\begin{array}{l}\text { Phulpur, } \\
\text { mymensingh }\end{array}$ & 42 & 36 & 53 & 47 & \\
\hline
\end{tabular}

Source: first annual report CBFM-2 project, 2002 
Table 4 Examples of lease values of selected waterbodies under SCBRMP in Sunamganj, Bangladesh

\begin{tabular}{llccc}
\hline SL. no. & $\begin{array}{l}\text { Name of the } \\
\text { water body }\end{array}$ & $\begin{array}{l}\text { Water body } \\
\text { area (ha) }\end{array}$ & $\begin{array}{l}\text { Lease value Tk/ } \\
\text { ha in 2008-09 }\end{array}$ & $\begin{array}{c}\text { Fish production/ } \\
\text { ha 2008-09 }\end{array}$ \\
\hline 1 & Terazani Balir Dubi & 1.72 & 20,867 & 1480 \\
2 & Sudam khali river & 3.48 & 8276 & 351 \\
3 & Chinamara beel and Gozaria & 1.23 & 7479 & 365 \\
& Dohor & & & \\
4 & Aislauni Prokashito Mitar Dubi & 1.55 & 7187 & 429 \\
5 & Ghotghatia Nodhi & 6.73 & 5706 & 116 \\
6 & Srinathpurer Dhola & 3.56 & 1551 & 28 \\
7 & Moinpur Beel Group & 4.75 & 1162 & 251 \\
8 & Babonpai Beel & 12.74 & 824 & 83 \\
9 & Basker Khal & 4.7 & 454 & 142 \\
10 & Boiragimara Beel & 18.7 & 428 & 124 \\
\hline
\end{tabular}

relationship with area or production. Besides, current leasing arrangements fail to support the aim of sustainable and equitable management by fishers.

There is no defined mechanism for adjusting lease value down to a reasonable level when waterbodies are transferred to a project. MoL claims a $25 \%$ higher lease value over its previous rate when this happens. Whereas, there are many examples of massive mismanagement of the leasing system and corrupt practices that surround it. Government is losing revenue on two ways: firstly a handful numbers of waterbodies remain unsettled for leasing for several years consecutively. Secondly, influential people backed by the politicians do not allow anyone to drop the schedule for competing in the tender process. This situation creates opportunity for the revenue department officials to fix least value and present considerable loss of government revenue.

There is lack in right information on productivity of waterbodies; a perfect market in bidding process is not yet developed. As a result, past bidding is not a sound basis for fixing lease values for fisheries to be managed by communities; it just provides a basis of the past lease value which preserves government revenue rates. It is expected that evidence including information on production and income levels at the waterbody and household levels will guide overall policy decisions on effective and sustainable fishery management benefiting poor people. However, in the short term there is a need to provide an enabling environment for the communities managing waterbodies without excess levels of government revenue being levied which can prevent fishers from earning enough to make conservation and sustainable management. The actual lease values in some water bodies have been summarized in Table 5 . Based on this there is a strongly skewed range of leases in per ha terms with a few very high leases pushing the mean up.

Table 5 Lease values in CBFM-2 waterbodies (Jalmahal) where revenue were collected (2000-2001) from the project area

\begin{tabular}{lccc}
\hline Water body type & Total number & Average lease value (Tk. per ha) Range lease \\
& & & value (Tk. per ha) \\
\hline Closed beel & 14 & 3057 & $36-28,781$ \\
Open beel & 22 & 2011 & $215-8857$ \\
River & 3 & 780 & $236-1833$ \\
\hline
\end{tabular}


It is not clear what should be done to address the inconsistencies regarding revenue collection from rivers. Evidence suggests that there some rivers with under NFMP for which revenue has been deposited, while from others revenues are not collected. Information from a small number of water bodies should not be used as the basis for fixing lease values more widely.

Finally, though the contribution of waterbodies to the total government revenue is insufficient in terms of total income, these resources have high importance to local elite and government officials. In this regard recommended fisheries management procedures based on sound biological management to ensure sustainability through conservation measures is rarely achieved. Rather practices of overexploitation and habitat/ wetland loss will continue to occur as they did in the past. It is suggested that, whatever the type of waterbody, an area should be set aside by the community as a permanent fish sanctuary then there should be a reduction in the lease value. This will encourage communities to protect part of their water bodies as fish sanctuaries.

\section{Value added tax (vat) and income tax}

Some inequitable rules have been imposed regarding tax revenue earnings from waterbodies. For example the lease value of a water body leased out to a project will be based on the previous year's lease price plus an additional $25 \%$ in the first year. In addition, fishers also have to pay $15 \%$ VAT and $3 \%$ income tax for each water body leased. The increase in VAT and income tax places an additional burden on poor fishers. National taxable net income is now Tk.160,000 per year but most of the fishers involve in fishery management live below subsistence level.

This matter had been debated in various fora but no change has occurred. There are serious institutional constraints facing the Ministry of Fisheries and Livestock and Department of Fisheries in this regard as the power to issue leases rests belongs to the Ministry of Land and Ministry of finance (MoF). A thorough review is therefore necessary in order to assess the condition of the resources lease, the income and welfare conditions of the fishers and revenue needs of Government. It is notable that the acceptable price for access to a government waterbody for a single entrepreneur with no interest in long-term sustainability of resource use may be much greater than the lease value that a poor community participating in fishery management with the intention of ensuring resource sustainability without short term over-exploitation and sharing the benefits among many fishing households is able to afford.

\section{Social barriers}

The distribution of benefits arising from fisheries depends on correct identification of stakeholders such as genuine fishers. In Bangladesh a wide range of interest groups use or gain benefits from fisheries. The prime users of fisheries resources include fishers, waterbody lessees, inhabitants of nearby communities, and local elites. In addition, various enhancement and management approaches are complicated by traditional attitudes towards women's' involvement in open water fisheries management. In most areas women are not encouraged to participate in community based management, with a few exceptions found in CBOs organized by projects (Thompson et al. 2001). Female participation in $\mathrm{CBOs}$ is low and most $\mathrm{CBOs}$ women have no position at the highest level of 
leadership. Social barriers may therefore act to exclude certain resource users who are directly or indirectly depend on fisheries.

\section{Stakeholders}

Sustainable inland fisheries management program need to correctly identify the stakeholders who will participate in management activities. However, due to diverse character of waterbodies in different regions of Bangladesh and the communities that depend on them is difficult to make define separate categories of stakeholder for fisheries management. As a result, ensuring access to fisheries resources by the appropriate stakeholders is a critical factor in ensuring the effectiveness of interventions. Despite the community based initiatives of different projects, fishery management is widely influenced by people from other more powerful social classes who are not directly dependent the resources themselves. Fishers are therefore often unable to establish their right to access waterbodies since the rural power elite are in a better position to maintain their access with low transaction costs by using their social connections, and the poor therefore lose out (Toufique 2000).

\section{Fishers}

Historically, fishing is an occupation and principal source of livelihood associated with certain communities. These groups are the key plays in fisheries management. Generally in Bangladesh fishers are categorized into three broad groups namely, professional or full-time fisher, seasonal or part-time fisher and subsistence fisher or occasional fisher. Ensuring access to fishery resources by the appropriate stakeholders is an important factor in successful fisheries management. Despite the community based initiatives of various projects, fishery management remains widely influenced by classes of people who are not direct users of fishery resources. As a result, fishers are often unable to establish theirs right to waterbodies. In contrast, the rural power elite is better placed to maintain access rights with lower transaction costs by using their social connections at the expense of the poor (Toufique 2000).

\section{Lease holders}

During the British colonial regime 1793 waterbodies were under the control of Zaminder (landlords). At that time fish stocks were abundant and revenue was collected mainly from land. In 1951 the Zamindari system was abolished and the Department of Revenue under the MOL assumed the responsibility for all Jalmohals outside Reserved Forest areas. The first initiative to give access right poor fishers was taken in 1965. In 1974 preference was given to co-operative societies registered with the Dept of Co-operatives. However, this provision created ill practice as a result of leaseholders using co-ops as fronts in order to take Jalmohals on sublease arrangements and retain effective control of the fishery. In 1980 government ordered the handover of all Jalmohals from MOL to the MOFL.

However, in 1983 before this new management system was fully implemented government shifted to another policy under which waterbodies less than 20 acres were transferred to the newly formed Upazila Parishad (sub-district councils) as a means of augmenting their income, whilst those over 20 acres reverted to MOL control, although 
with $50 \%$ of the income accruing from these earmarked for Upazila Parishad. The NFMP was adopted in 1986 to provide access to genuine poor fishers and promote fisheries management and conservation in association with the Department of Fisheries (DOF). About 400 waterbodies were brought under this management system. Another shift in waterbody management took place in 1991, when a tendering procedure was introduced among fishers society for the leasing of Jalmahal. None of these policy shifts created positive impacts on fish catch and bio-diversity as leaseholders' main intention in each instance continued to be profit maximization. In order to ensure this outcome leaseholders employ middlemen (sub-lessees) or local musclemen to exclude real fishers in the fishing process. This enables them to use illegal fishing practices to extract the highest yields of fishes wherever possible.

\section{Community members}

Communities located close to most waterbodies are mixed in terms of the combination of different professions (e.g. farmers, fishers, agricultural and non agricultural day laborers, full-time workers in formal employment, and businessmen). The outcomes of various CBFM projects show that socially more homogenous communities are generally more effective for fisheries management. In most communities where waterbody users reside, few households are truly traditional full time professional fishers or converted to fishing. Other people engage in a variety of other related and non-related economic activities, while many people catch fish seasonally for food and/or income. Some landowners convert floodplain land into ditches for trapping fish during the monsoon and harvest for consumption or income in winter.

\section{Local elites}

In most cases control over natural resources has not been devolved to the poor fishers or even the middle strata of communities due to elite capture of these resources. Open water fisheries have been controlled by a small number of powerful elite's, who had developed good connections with local government officials and thus obtained a disproportionate share of power (David Lewis 2008). At the same time, the fishers with whom community based management projects work are often helplessly caught up in the meshes of this invisible network which they only partially understand, and possess only a very small amount of power. Thus poor fishers and other community members are excluded from the decision making process.

\section{Role of local government institution}

The existing practice of co-management depends heavily on the establishment of local institutions such as Community Based Organizations (CBOs). Ensuring the sustainability of these institutions requires capacity building initiatives in order to support the development of democratic practices, establish and fiscal discipline and the participation of other local level institutions. The project therefore aimed to improve the management capacities of CBOs using both formal and informal methods of knowledge dissemination such as discussions, meetings and training. The project aimed to create a network of CBOs with a view to developing a sustainable institution, encouraging dissemination of 
fishery management information and enabling these organizations to respond to various issues efficiently and effectively.

\section{Conclusion}

This study concludes that open water fisheries management through community involvement has promising future. However, despite the successes, a number of challenges were also evident and need to be noted for overcome the hinderers. These benefits and constraints are summarized below as initiatives for overcoming the challenges.

- Open water fisheries development activities were undertaken through the partnership of NGOs, Government and an international research institute working to assess the impacts of these approaches (particularly on poor people and fishers), their sustainability (institutional, social, economic, and biological), and the potential for expansion.

- Regular project activities to identify test and assess co-ordination and administration mechanisms for community management arrangements within larger fishery and wetland systems. Based on the view that for CBFM to be effective in the long term and over larger areas, but it will need to operate within co-management frameworks that help distinct user communities share information and experiences and coordinate their management activities.

- CBFM works to inform and influence all fisheries policy stakeholders of improved management approaches. For this there are a mixture of policy and communication studies, legal studies and advice, and media development for awareness rising at different levels.

- CBFM has been developed and tested a range of community based fisheries management approaches and models in different types of water bodies for overcoming the challenges. Three models have been identified for managing inland open water fisheries. These are, Fisher managed fishery, Community managed fishery and women managed fishery.

- The community Based Fisheries Management Project has addressed and mobilized the communities and local government for open water management and to put forward for habitat restoration and conservation in an attempt to link micro and macro levels of stakeholders. Otherwise the huge potential of open water fisheries sector will be overexploited and destroyed for the increasing population of Bangladesh.

Authors' contributions

AKMFK: paper drafted including data analysis; completed mostly abstract, introduction, method, review section and references. MGM: completed Fishers section and partly completed Challenges, Introduction, Review and Reference section; reviewed and edited 2 nd draft (including all sections) and competed Fishers section. MNN: reviewed and edited final draft and, partly competed abstract, review and reference sections. All authors read and approved the final manuscript.

Author details

1 The WorldFish Center, Bangladesh and South Asia office, House 22B, Road 7, Block F Banani, Dhaka 1213, Bangladesh.

2 Department of Zoology, Faculty of Biological Sciences, University of Dhaka, Dhaka 1000, Bangladesh.

Competing interests

The authors declare that they have no competing interests.

Received: 17 December 2015 Accepted: 17 December 2015

Published online: 04 January 2016 
References

BBS. 2001. Statistical Pocket Book Bangladesh 2001. Bangladesh Bureau of Statistics, Ministry of PlanningGovernment of People's Republic of Bangladesh.

Dickson, M. ed. 2006. Community based fisheries management, the right option. policy brief 4. Bangladesh: The WorldFish Center.

Dickson, M., and Usha, K. 2006. Turning the tide, Community based fisheries management, protecting the poor and the environment.

Huda, A.T.M.S. 2003. Fishing in muddy water: policy process for inland fisheries in Bangladesh. Community Based Fisheries Management Project (CBFM-2) Working Paper 3. 11-27. Dhaka: WorldFish Center.

IFAD. 2006. Supervision Report of the International Fund for Agricultural Development, Community Based Fisheries Management: South and Southeast Asia. TAG-531: CBFM-SSEA.

Khan, A.K.M., and H. Middendrop. 2006. Technical Advisory Notes (TAN) Bangladesh and Vietnam. Bangladesh: The WorldFish Center.

Kuperan, K. V., Jesper, Raakjaer Nielsen, Poul Degnbol, Mahfuzuddin Ahmed, Mafaniso Hara, and Nik Mustapha Raja Abdullah. 2003. Co-Management_-policy brief finding from a worldwide study: WorldFish Center policy brief. WorldFish Center contribute \#1696.

Lewis, David, and Hossain, Abul. 2008. Beyond 'the Net'? Institutions, elites and the changing power structure in Rural Bangladesh. In Local Democracy in South Asia Microprocesses of Democratization in Nepal and its Neighbours, ed. David Gellner, Krishna Hachhethu. India: SAGE Publications Pvt. Ltd.

Mustafa, M.G. 2009. Fishery resources trends and community-based management in the river Titas in Bangladesh. International Journal of River Basin Management 7: 135-145.

Mustafa, M.G., G.N. Islam, and K.A.K.M. Firoz. 2007. Community Based Fisheries Management CBFM-SSEA, Fisheries and Livelihoods Impact. Bangladesh: The WorldFish Center.

Naser, M., and Niamul. 2014. Fish conservation efforts in Bangladesh: how to make it more effective. In Proc. of The Festschrift on the 50th Anniversary of the IUCN Red List of Threatened Species ${ }^{\mathrm{TM}}$, 169-173p. Dhaka: IUCN Bangladesh.

Rahman, A.K.A. 2005. Freshwater fishes of Bangladesh, 2nd ed, 394p. Dhaka: Zoological Society of Bangladesh, Dept. of Zoology, Univ. of Dhaka.

Sultana, P., and Thompson, P. 2000. Community Fishery Management Implication for Food Security and Livelihoods. Paper presented at the International Institute of Fisheries Economics and Trade conference at Covallis, Oregon on 10-14 July, 2000.

Thompson, P.M., and M.M. Hossain. 1998. Social and Distributional Issues in Open water Fisheries Management in Bangladesh, In Inland Fishery Enhancements, ed. Petr Thompson, 374:351-370. Rome: FAO Fish Tech Pep.

Thompson, P.M. 2004. Impacts of the Community Based Fisheries Management Project Phase 1. Report to the WorldFish Center, Bangladesh, March 2004. 107 pp.

Thompson, P. M., Sultana, P. Islam, M.N., Kabir, M.M., Hossain, M.M., and Kabir, M.S., 1999. An assessment of co-management arrangements developed by the Community Based Fisheries Management Project in Bangladesh. Paper presented at the international workshop on fisheries co-management, 23-28 Aug 1999, Penang, Malaysia.

Thompson, P.M., Parvin, S., Islam, N., Nazmul Islam, S. M., M. Mokarram Hossain, M.M., and Anup, K.S., 2001, Lessons from community based management of floodplain fisheries in Bangladesh.

Thompson, P.M., A.K.M. Firoz Khan, and M.M. Muzaffar Ahmed. 2004. Issues and project changes first annual report CBFM-2, Dhaka 2004. Dhaka: TheWorldFish Center.

Toufique, and Kazi Ali. 2000. "Property Rights, Livelihoods, and Poverty around Some Fishing Grounds in Rural Bangladesh." Presented at "Constituting the Commons: Crafting Sustainable Commons in the New Millenium", the Eighth Conference of the International Association for the Study of Common Property, Bloomington, Indiana, USA, May 31-June 4.

\section{Submit your manuscript to a SpringerOpen ${ }^{\circ}$ journal and benefit from:}

- Convenient online submission

Rigorous peer review

- Immediate publication on acceptance

- Open access: articles freely available online

- High visibility within the field

- Retaining the copyright to your article

Submit your next manuscript at $\gg$ springeropen.com 